\title{
An unexpected cause for right loin pain
}

\author{
Roberta Callus, Josef Micallef
}

Department of Medicine, Mater Dei Hospital, Msida, Malta

\section{Correspondence to} Dr Roberta Callus, robertacallus@yahoo.co.uk

Accepted 2 July 2015

\section{DESCRIPTION}

A 49-year-old woman presented with acute onset of persistent, severe right loin pain. This was associated with uncontrolled hypertension. There was no associated fever, haematuria or dysuria. There was no history of trauma. At 17 years of age, she underwent a left nephrectomy for an atrophic kidney (figures 1-3).

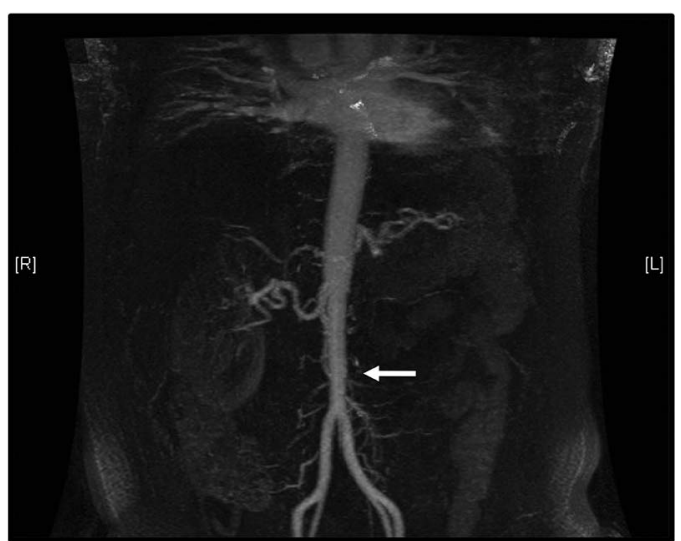

Figure 1 MR angiography in 2012 showed a normal sized right kidney with normal calibre of the renal artery but narrowing of the infrarenal abdominal aorta (arrow).
The patient was monitored closely, as worsening pain may be indicative of a rapidly expanding aneurysm or impending rupture. Flank pain has been documented in up to $6 \%$ of unruptured renal artery aneurysms (RAAs). ${ }^{1}$ All other possible aetiologies for the flank pain in our patient were excluded.

Following discussion with the vascular surgeons and interventional radiologists, surgical intervention was deemed high risk due to the patient's single kidney.

RAAs are relatively uncommon, however, they have been more frequently diagnosed with the introduction of visceral angiography. ${ }^{12}$ Associated diseases and risk factors include fibromuscular dysplasia, intrinsic collagen deficiencies, connective tissue diseases, arteriosclerosis, vasculitides and hypertension. RAAs are more common in females. Although most are asymptomatic, they may present with hypertension, flank or abdominal pain, haematuria and acute haemodynamic collapse.

Rupture has been reported in about $3 \%$ of cases, ${ }^{1}{ }^{2}$ however, it is associated with mortality in less than $10 \% .^{3}$ Risk of rupture increases in pregnancy and with enlarging aneurysms. Some consider calcification to be protective. ${ }^{2} 3$ Indications for treatment, although controversial, include local

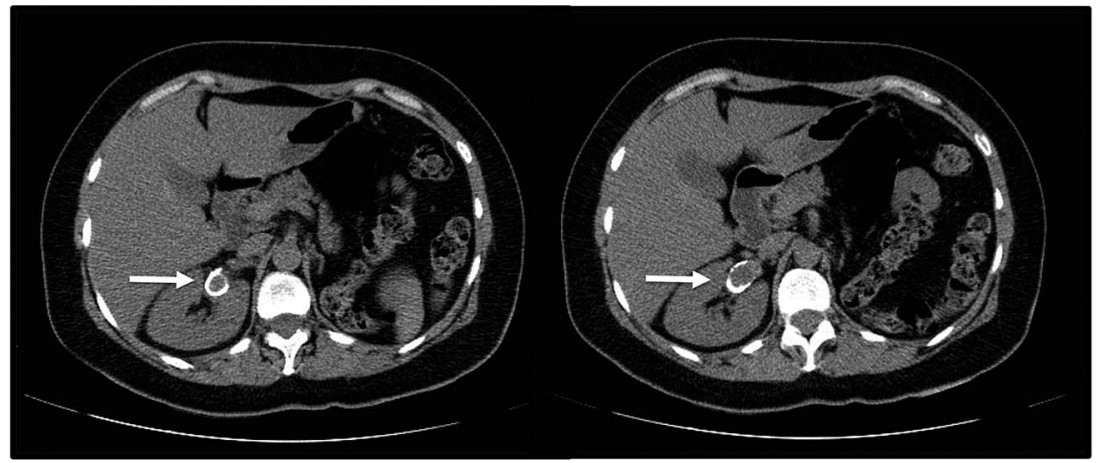

Figure 2 CT imaging of the urinary tract performed on presentation. Axial CT images at the level of the kidneys showed an oval calcified structure at the hilum of the right kidney (arrows). Note the absent left kidney.

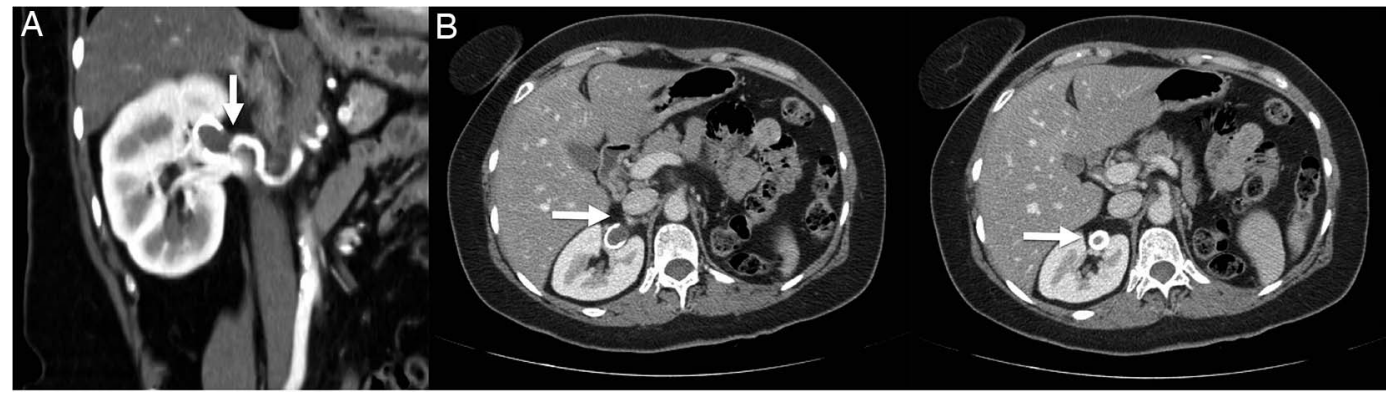

Figure 3 Contrast-enhanced CT imaging revealed a $2.5 \times 1.5 \mathrm{~cm}$ partially thrombosed, saccular right renal artery aneurysm (RAA) with ring-shaped calcification (arrows). The density of the central part of the aneurysm is $34 \mathrm{HU}$. (A) Sagittal view and (B) axial views. 
symptoms, large $(>2 \mathrm{~cm})$ or enlarging aneurysms and those with evidence of dissection or rupture. ${ }^{13}$ Females of childbearing age should also be treated. ${ }^{12}$

Successful endovascular treatments include coil embolisation and stent graft placement. ${ }^{1}$ Invasive surgery may be required for complex cases.

\section{Learning points}

- Most renal artery aneurysms (RAAs) are found incidentally and are asymptomatic.

- RAAs, although uncommon, may present with sudden loin pain.

- A decision for surgical intervention depends on the individual case, and should involve a multidisciplinary team approach.
Contributors $\mathrm{RC}$ and JM were involved in the management of the patient and in the preparation of the manuscript.

Competing interests None declared.

Patient consent Obtained.

Provenance and peer review Not commissioned; externally peer reviewed.

\section{REFERENCES}

1 Klausner JQ, Lawrence PF, Harlander-Locke MP, et al. The contemporary management of renal artery aneurysms. J Vasc Surg 2015;61:978-84.

2 Mondek P, ZIta Z, Sefranek V, et al. Kidney salvage after urgent repair of large ruptured renal artery aneurysm - case report and review of the literature. Eur J Vasc Endovasc Surg 2003;6:67-9.

3 Henke PK, Cardneau JD, Welling TH III, et al. Renal artery aneurysms: a 35-year clinical experience with 252 aneurysms in 168 patients. Ann Surg 2001;234:454-63.

Copyright 2015 BMJ Publishing Group. All rights reserved. For permission to reuse any of this content visit http://group.bmj.com/group/rights-licensing/permissions.

BMJ Case Report Fellows may re-use this article for personal use and teaching without any further permission.

Become a Fellow of BMJ Case Reports today and you can:

- Submit as many cases as you like

- Enjoy fast sympathetic peer review and rapid publication of accepted articles

- Access all the published articles

- Re-use any of the published material for personal use and teaching without further permission

For information on Institutional Fellowships contact consortiasales@bmjgroup.com

Visit casereports.bmj.com for more articles like this and to become a Fellow 